\title{
Rapid and Sensitive Spectrophotometric Method for the Determination of the Trace Amount of Thallium (III) in Water and Urine Samples by New Oxidative Coupling Reaction
}

\author{
Padmarajaiah Nagaraja, Naef Ghllab Saeed Al-Tayar, Anantharaman Shivakumar, \\ Ashwinee Kumar Shresta, and Avinash K. Gowda
}

\begin{abstract}
Department of Studies in Chemistry, University of Mysore, Manasagangotri, Mysore 570 006, India. Phone: +91-821-2412557, Fax:+91-821-2421263.drpn58@yahoo.co.in
\end{abstract}

Received May 2, 2009; accepted November 11, 2009

\begin{abstract}
A very simple, sensitive and fairly selective direct spectrophotometric method is presented for the rapid determination of thallium(III) at trace level. The method is based on the oxidation of 2-hydrazono-3-methyl-2,3-dihydrobenzo[ $d]$ thiazole hydrochloride (MBTH) by thallium(III) in phosphoric acid medium to form a diazonium cation, which couples immediately with 10,11-dihydro- $5 \mathrm{H}$ dibenzo $[b, f]$ azepine (IDB) at room temperature giving a blue colored species having a maximum absorption at $660 \mathrm{~nm}$. The reaction conditions and other important analytical parameters were optimized. The calibration curve was found to be linear over the range of 0.1-4 $\mu \mathrm{g} / \mathrm{mL}$ with molar absorptivity of $4.5 \times 10^{4} \mathrm{~L} \mathrm{~mol}^{-} \mathrm{cm}^{-1}$ and Sandell's sensitivity of $0.00454 \mu \mathrm{g} \mathrm{cm}^{-2}$. The relative standard deviation and limit of detection have been found to be $0.58 \%$ and $0.0147 \mu \mathrm{g} / \mathrm{mL}$ respectively. Almost all common anions and cations are found not to interfering in matrix level of the analytical process. The method has been successfully applied for the determination of thallium(III) in synthetic standard mixtures, water and human urine samples. The performance of proposed method was evaluated in terms of student's t-test and variance ratio F-test, to find out the significance of proposed method over the reported methods.

Key words: Thallium determination; MBTH; IDB; Spectrophotometry; Water samples, Urine samples.
\end{abstract}

\section{Introduction}

Determination of thallium (III) in environmental samples is of great importance because of high toxicity of both element and its compounds. Some thallium compounds have been used as rodenticides, insecticides, fungicides [1], medicines, and electronics and in the manufacture of optical glasses with high refractive indices. Thallium is a well-known neurotoxicant [2], and has become a very important pollutant of the environment. Short times exposure of thallium causes disorders of the nervous system and gastrointestinal irritation. In long term, it has got potential to cause changes in blood chemistry damage to liver, kidney, intestinal and testicular tissues, and causes hair loss, abdominal pain, diarrhea and tingling in the four extremities [3, 4]. In human body system, thallium is absorbed through the skin and gastrointestinal track, which can be identified in urine within a few hours [5]. The US Environmental Protection Agency (US EPA) has listed thallium as a pollutant among the 129 "priority pollutants". It is regarded as one of the most toxic of the heavy metals, causing both chronic and acute poisoning [6]. The Maximum Contaminant Level Goal
Resumen. Se presenta un método espectrofotométrico directo muy simple, sensible y bastante selectivo para la determinación de talio (III) a nivel de trazas. El método se basa en la oxidación de clorhidrato de 2-hidrazono-3-metil-2,3-dihidrobenzo[d]tiazol (CTMB) por talio (III) en medio de ácido fosfórico para formar un catión diazonio, el cual se copula inmediatamente con 10,11-dihidro- $5 \mathrm{H}$ dibenzo $[b, f]$ azepina (IDB) a temperatura ambiente dando especies de color azul con un máximo de absorción a $660 \mathrm{~nm}$. Se optimizaron las condiciones de reacción y otros parámetros analíticos importantes. Se encontró que la curva de calibración fue linear en el intervalo de $0.1-4 \mu \mathrm{g} / \mathrm{mL}$ con una absortividad molar de $4.5 \times 10^{4} \mathrm{~L} \mathrm{~mol}^{-} \mathrm{cm}^{-1} \mathrm{y}$ una sensibilidad de Sandell de $0.00454 \mu \mathrm{g} \mathrm{cm}^{-2}$. La desviación estándar relativa y el límite de detección fueron $0.58 \%$ y $0.0147 \mu \mathrm{g} / \mathrm{mL}$, respectivamente. Se encontró que casi todos los aniones y cationes comunes no interfieren a nivel de la matriz en el proceso analítico. El método fue exitosamente aplicado para la determinación de talio (III) en mezclas de referencia sintéticas, agua y muestras de orina humana. La realización del método propuesto fue evaluada en términos de la prueba $t$ de student y la prueba $F$ de relación de varianzas, para averiguar el nivel de significancia del método propuesto con respecto a otros métodos reportados.

Palabras clave: Determinación de talio; CTMB; IDB; espectrofotometría; muestras de agua, muestras de orina.

(MCLG) and Maximum Contaminant Level (MCL) considered by US EPA for thallium are $0.0005 \mathrm{mg} / \mathrm{L}$ and $0.002 \mathrm{mg} / \mathrm{L}$, respectively [7]. The main sources of thallium pollution at present are cement production and fossil fuel combustion, and also, in the metallurgical processes of lead and zinc production. Due to great concerns regarding the toxicity of thallium and its derivatives, there is growing need for improved analytical methods for monitoring this metal [8]. Consequently, accurate determination of thallium using simple and rapid method is of paramount importance to deal safely with the environment.

Some spectrophotometric methods have been proposed for the determination of thallium which include phenosafranine [9], semi methyl thymol blue [10], 2-hydroxy-3-carboxy5-sulfenyl-diazoamino azobenzene [11], 4-nitrobenzenediazoaminoazobenzene (cadion)+TX-100 [12], brilliant green [3], $N, N$ '-diphenylbenzamidine $[14,15]$, pyronin $\mathrm{G}[16]$, mepazin hydrochloride [17], alizarin violet [18], 4-(4'-N,N-dimethylaminophenyl) urazol [19], methiomeprazine hydrochloride [20], 9,10-phenanthaquinone monoethylthiosemicarbazone [21], trifluperazine hydrochloride [22], and rhodamine B [23]. 
Most of the available colorimetric methods suffer from serious disadvantages such as poor selectivity. There are other analytical techniques applicable to thallium determination in environmental and industrial samples, which include mass spectrometry [24], laser-excited and induced atomic fluorescence spectrometry [25, 26], ICP/MS [8, 27, 28], anodic stripping voltammetry [29-32], adsorptive cathodic stripping voltammetry [33], electrothermal atomic absorption spectrometry [34-36], and flame atomic absorption spectrometry [37- 40]. Most of these methods have disadvantages with respect of cost and instrumentation. From these it is evident that numerous analytical techniques have been developed and applied to thallium determination in environmental and industrial samples. But some of these analytical methods use reagents or generate chemical wastes, which are toxic [23]. As a consequence, the analytical methods with high performance but which are not environmentally friendly are not acceptable. Hence, there is a great need to develop methods which are less harmful to human and to the environment as one of the basic principles of Green Chemistry [41]. This has encouraged the investigators to develop analytical methods for the determination of thallium in various samples. In the present investigation, we have proposed a method for determination of thallium by using 2-hydrazono-3-methyl-2,3-dihydrobenzo[ $d]$ thiazole hydrochloride (MBTH) and 10,11-dihydro-5H-dibenzo[b,f]azepine (IDB) in phosphoric acid medium. The reaction involves the oxidation of MBTH by thallium (III), which quantitatively couples with IDB forming blue species in phosphoric acid medium. The proposed method reports a sensitive, selective, simple, rapid and reproducible spectrophotometric method for the determination of thallium, which makes use of reagents that are inexpensive. This method is also free from commonly interfering ions and does not require any extraction step, heating or close control of $\mathrm{pH}$. Furthermore, the method has been successfully applied for the determination of thallium in various synthetic, environmental and biological samples and the results are found to be reliable and reproducible.

\section{Results and Discussion}

MBTH gets oxidized by thallium (III) in an aqueous medium at room temperature to form diazonium cation, which instantaneously gets coupled with IDB in orthophosphoric acid medium, resulting in the formation of a blue colored species.

\section{Spectral characteristics}

In proposed method a blue colored product was formed and to have minimum interferences, it was necessary to found out the optimum wavelength for thallium determination. This wavelength must be specific for the quantitative and specific monitoring of Thallium-MBTH-IDB. The wavelength of maximum absorbance was identified by scanning the blue colored product over the range 400-750 $\mathrm{nm}$ with different concentrations of thallium(III). The optimum wavelength for getting the best

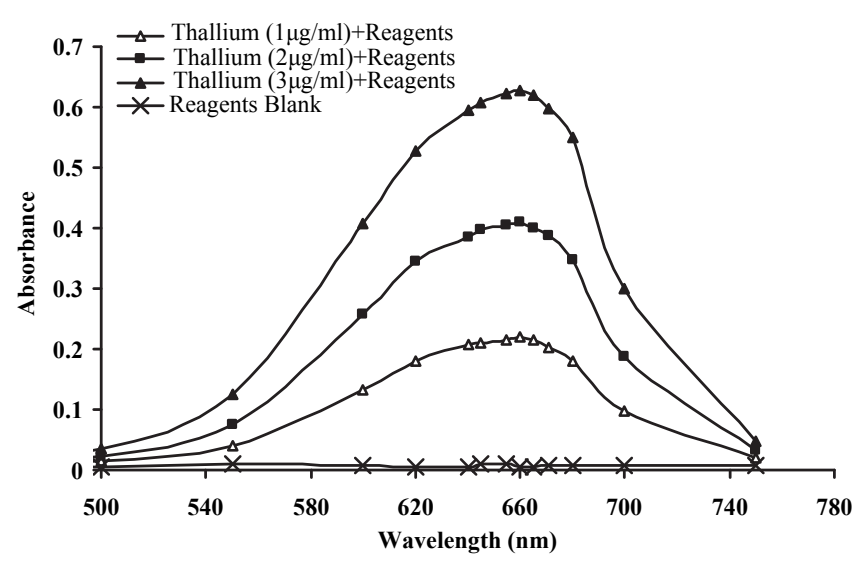

Fig. 1. Absorption spectra of Thallium(III) with MBTH and IDB.

results was found to be $660 \mathrm{~nm}$ and the reagent blanks had negligible absorption at this wavelength. The absorption spectra of the product are shown in Fig. 1.

\section{Optimization of reaction conditions}

The effect of MBTH and IDB were studied by using a fixed concentration of thallium(III) in $10 \mathrm{~mL}$ standard flasks. It was found that $0.05 \% \mathrm{MBTH}$ in the range of $0.5-2 \mathrm{~mL}$ was necessary to obtain maximum color intensity. Hence, $1 \mathrm{~mL}$ of $0.05 \% \mathrm{MBTH}$ was used for further studies. Various volumes of $0.1 \%$ IDB were studied, and the best results were obtained at $0.5-2 \mathrm{ml}$ of IDB. Therefore $1 \mathrm{~mL}$ of $0.1 \%$ IDB was selected for further studies. Similar experiments were carried out with the above concentrations and volumes to study the effect of different acids on the stability and sensitivity of the colored species. Various acids like hydrochloric acid, orthophosphoric acid, sulphuric acid and acetic acid were used at their optimum concentrations. It was observed that, hydrochloric acid did not give color instantaneously, whereas sulphuric acid gave absorbance but had less sensitivity and stability. Although acetic acid gave high absorbance, the selectivity was less. Orthophosphoric acid showed highest sensitivity, selectivity, linearity and stability of blue colored product and the blank remained colorless. Hence, $1 \mathrm{~mL}$ of $3 \mathrm{M}$ orthophosphoric acid was chosen as the optimal acidic medium for the determination of thallium(III) in total volume of $10 \mathrm{~mL}$ to give maximum color intensity as well as stability of the colored product. The calibration graphs were plotted for the results obtained for the determination of different concentrations of thallium(III) within Beer's law range as shown in Fig. 2.

\section{Analytical data}

The applicability of the proposed analytical technique was tested by recording absorbance of a series of solutions, containing varying amounts of thallium within the Beer's law limit, against the corresponding reagent blank at $660 \mathrm{~nm}$. The Beer's law limits, molar absorptivity, Sandell's sensitivity and 


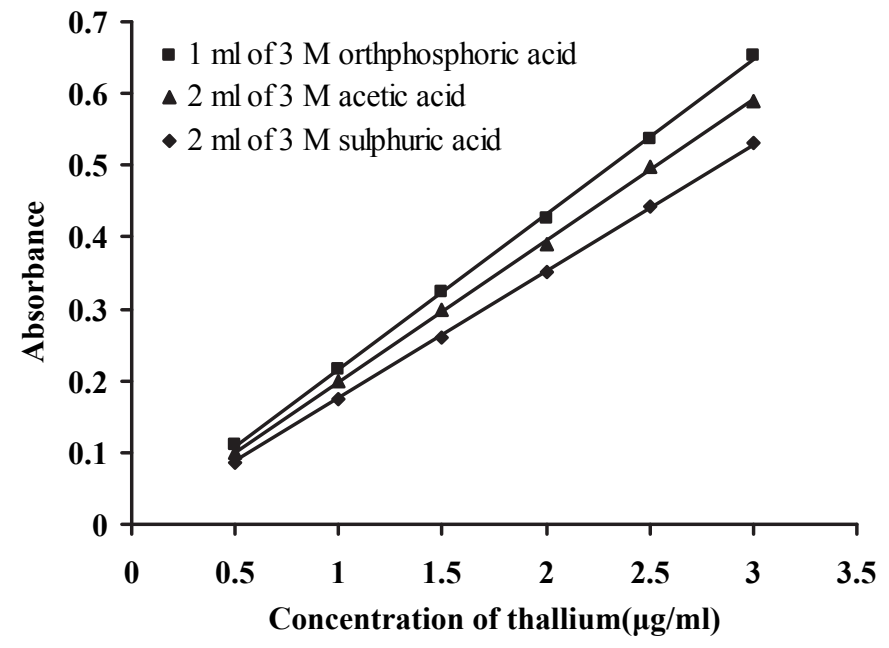

Fig. 2. Effect of different acids on the colored product.

optimum range by spectrophotometric determination are summarized in Table 1. The table also presents slope, intercept and relative standard deviation.

\section{Effect of interfering species}

Interfering species in the analysis was investigated using $2 \mu \mathrm{g} /$ $\mathrm{mL}$ of thallium (III) with varying amounts of potential interfering species and complexing agents. More than thirty different ions were tested for their possible interferences in the determination of thallium. However, the interference by $\mathrm{Fe}^{+2}, \mathrm{Fe}^{+3}$ ion and $\mathrm{NO}_{2}{ }^{-}$could be easily eliminated by the addition of 2 $\mathrm{mL}$ of $0.3 \mathrm{M}$ sodium fluoride and $2 \mathrm{~mL}$ of $1 \mathrm{M}$ sulphamic acid, respectively, interference by $\mathrm{CO}_{3}^{-2}$ was eliminated by $\mathrm{pH}$ control $(\mathrm{pH}=4)$ by using $3 \mathrm{ml}$ of acetate buffer solution $(1.5 \mathrm{ml}$ of $0.2 \mathrm{M}$ of sodium acetate and $8.5 \mathrm{~mL}$ of $0.2 \mathrm{M}$ of acetic acid). A deviation of $\pm 3 \%$ from the original value in the absorbance reading was considered to be acceptable. The interferences by some species are presented in Table 2.
Table 1. Optical parameters for the determination of Thallium(III).

\begin{tabular}{|c|c|}
\hline Parameters & Characteristic \\
\hline Colour & Blue \\
\hline$\lambda_{\max }(\mathrm{nm})$ & 660 \\
\hline Stability (h) & 36 \\
\hline Beer's law range $(\mu \mathrm{g} / \mathrm{mL})$ & $0.1-4$ \\
\hline Molar absorptivity $\left(1 \mathrm{~mol}^{-1} \mathrm{~cm}^{-1}\right)$ & $4.5 \times 10^{4}$ \\
\hline Optimum photometric range $(\mu \mathrm{g} / \mathrm{mL})$ & $0.2-3$ \\
\hline Sandell's sensitivity $\left(\mu \mathrm{g} \mathrm{cm}^{-2}\right)$ & 0.00454 \\
\hline Detection Limit. $(\mu \mathrm{g} / \mathrm{mL})$. & 0.0147 \\
\hline Quantification Limit. $(\mu \mathrm{g} / \mathrm{mL})$. & 0.0445 \\
\hline \multicolumn{2}{|l|}{ Regression Equation $^{\mathrm{a}}$} \\
\hline Slope (a) & 0.209 \\
\hline Intercept (b) & 0.0018 \\
\hline Correlation coefficient & 0.9984 \\
\hline Standard deviation ${ }^{\mathrm{b}}$ & 0.275 \\
\hline Relative standard deviation ${ }^{\mathrm{b}}$ & 0.58 \\
\hline Reaction time (min) & 1 \\
\hline
\end{tabular}

${ }^{a} Y=a x+b$ where $\mathrm{x}$ is the concentration of thallium(III) in $\mu \mathrm{g} / \mathrm{ml}$.

${ }^{\mathrm{b}}$ Ten replicate measurements.

\section{Effect of time and temperature on color stability}

Under the optimum conditions, although the color developed instantaneously, $1 \mathrm{~min}$ was allowed to obtain the maximum and constant absorbance; the colored product was stable for $36 \mathrm{~h}$. The absorbance varied by not more than $\pm 3 \%$ over a period of $48 \mathrm{~h}$ and the color development was not affected by the temperature in the range of $10-90{ }^{\circ} \mathrm{C}$. Hence, for the routine analysis less than 1 min reaction at room temperature was sufficient.

Table 2. Effect of interfering ions on the spectrophotometric determination of thallium(III) $(2 \mu \mathrm{g} / \mathrm{mL})$.

\begin{tabular}{lccc}
\hline Interfering substance & Tolerance limit $(\mu \mathrm{g} / \mathrm{mL}$ & Interfering substance & Tolerance limit $(\mu \mathrm{g} / \mathrm{mL})$ \\
\hline Phenol & 100000 & $\mathrm{CO}_{3}^{2-\mathrm{c}}, \mathrm{Mo}^{6+}, \mathrm{Zr}^{4+}$ & 450 \\
Sulphamic acid & 50000 & $\mathrm{Al}^{3+}, \mathrm{Hg}^{2+}, \mathrm{SO}_{3}^{2-}$ & 200 \\
Urea & 40000 & $\mathrm{Fe}^{3+\mathrm{b}}$ & 150 \\
$\mathrm{Mg}^{2+}, \mathrm{SO}_{4}^{2-}, \mathrm{CH}_{3} \mathrm{COO}^{-}$ & 25000 & $\mathrm{NO}_{2}^{-\mathrm{a}}$ & 120 \\
$\mathrm{ClO}_{4}^{-}, \mathrm{PO}_{4}^{3-}, \mathrm{NH}_{4}^{+}$ & 10000 & $\mathrm{Ba}^{2+}$, Tartarate, $\mathrm{Br}^{-}$ & 50 \\
$\mathrm{Cd}^{2+}, \mathrm{Zn}^{2+}, \mathrm{Cl}^{-}, \mathrm{Na}^{+}, \mathrm{EDTA}, \mathrm{F}^{-}$ & 2000 & $\mathrm{~Pb}^{2+}, \mathrm{WO}_{4}^{2-}, \mathrm{Cu}^{2+}$ & 30 \\
$\mathrm{Ca}^{2+}, \mathrm{NO}_{3}^{-\mathrm{a}}, \mathrm{K}^{+}, \mathrm{Mn}^{2+}$ & 1750 & $\mathrm{Ce}^{4+}, \mathrm{SCN}^{-}$ & 10 \\
$\mathrm{Fe}^{2+}, \mathrm{Ni}^{2+}$ & 1000 & $\mathrm{I}^{-}$ & 5 \\
\hline
\end{tabular}

\footnotetext{
${ }^{\text {a }}$ Masking by addition $2 \mathrm{ml}$ of $1 \mathrm{M}$ sulphamic acid.

${ }^{\mathrm{b}}$ Masking by addition $2 \mathrm{ml}$ of $0.3 \mathrm{M}$ sodium fluoride.

${ }^{\mathrm{c}}$ Using of buffer solution $\mathrm{pH}=4$.
} 
Table 3. Effect of order of reactants addition.

\begin{tabular}{lcc}
\hline Serial No. & Order of addition $^{(\mathrm{a})}$ & Absorbance for $2 \mu \mathrm{g} / \mathrm{ml}$ \\
\hline 1 & $\mathrm{~A}+\mathrm{B}+\mathrm{C}+\mathrm{D}$ & 0.420 \\
2 & $\mathrm{~A}+\mathrm{B}+\mathrm{D}+\mathrm{C}$ & 0.420 \\
3 & $\mathrm{~A}+\mathrm{D}+\mathrm{C}+\mathrm{B}$ & 0.419 \\
4 & $\mathrm{~B}+\mathrm{C}+\mathrm{A}+\mathrm{D}$ & 0.420 \\
5 & $\mathrm{~B}+\mathrm{D}+\mathrm{A}+\mathrm{C}$ & 0.420 \\
6 & $\mathrm{~B}+\mathrm{D}+\mathrm{C}+\mathrm{A}$ & 0.419 \\
\hline
\end{tabular}

${ }^{\mathrm{a}} \mathrm{A}=\mathrm{MBTH}, \mathrm{B}=\mathrm{IDB}, \mathrm{C}=\mathrm{H}_{3} \mathrm{PO}_{4}, \mathrm{D}=$ Thallium(III)

\section{Order of addition of the reactants}

The effect of order of addition of the reactants was studied by using different orders of the optimized amounts of reactants following the proposed method. The results obtained have showed the order of reactants addition do not effect absorbance values as shown in Table 3 , but for maintaining the uniformity of the order of reactants addition, serial No.1 of Table 3, was followed throughout course of the determination of thallium(III).

\section{Reaction mechanism}

Under the reaction conditions, MBTH loses $2 \mathrm{e}^{-}$and a proton on oxidation with thallium (III) forming the electrophilic intermediate (active coupling species), which couples with IDB to give a blue colored product. The probable reaction pathway based on the reactivity of MBTH with aromatic amines [42 44] is shown in Fig. 3.

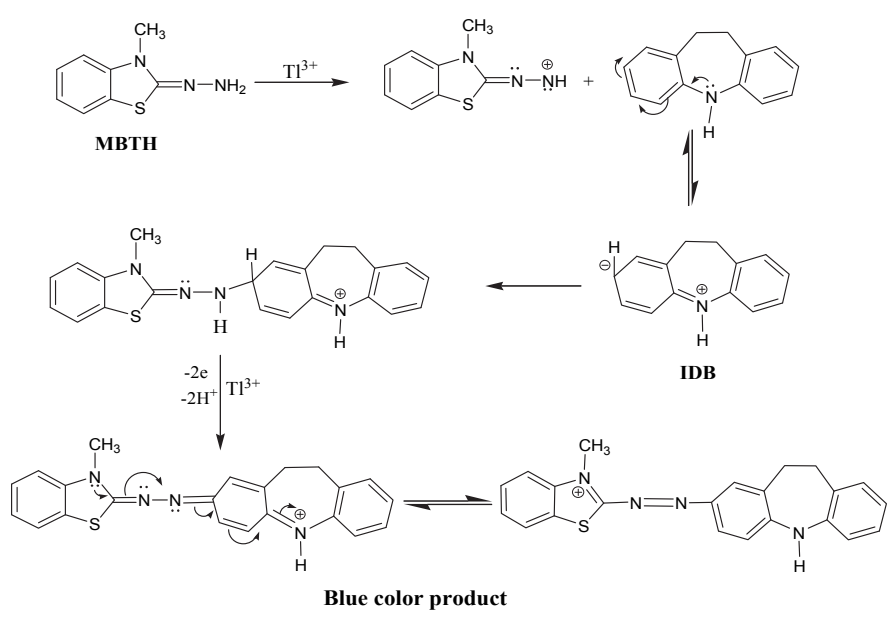

Fig. 3. Probable reaction pathway for the formation of colored product by MBTH and IDB.

\section{Performance of the proposed method and statistical comparison with reported methods}

The proposed method was applied for the determination of thallium by spiked environmental and biological samples with known quantity of thallium(III) and carrying out recovery studies. The results obtained by the proposed method were confirmed by measurements of thallium contents using the reported methods $[21,45]$. The results were analyzed statistically by Student's $t$-test and the variance ratio $F$-test at $95 \%$ confidence level. The calculated $\mathrm{t}$ and $F$-values did not exceed those theoretical values. It is evident from Table 4 , that there is no significant difference between the spiked

Table 4. Determination of Tl(III) in spiked different water and human urine samples by a proposed method and reported methods.

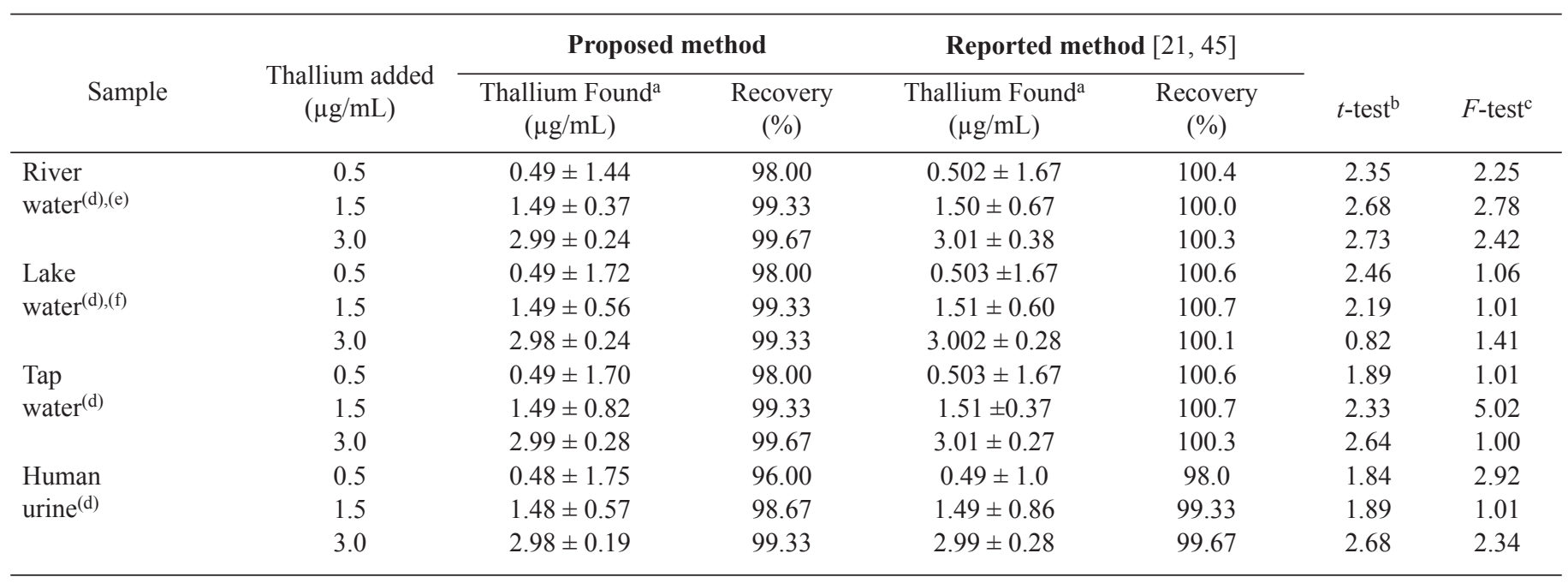

a Mean \pm Relative Standard Deviation $(n=5)$

b Tabulated $t$-value for eight degrees of freedom at $\mathrm{P}(0.95)$ is 2.78 .

c Tabulated $F$-value for $(4,4)$ degrees of freedom at $\mathrm{P}(0.95)$ is 6.39 .

${ }^{\mathrm{d}}$ Gave no test for thallium.

e Kukkaraheli lake- Mysore, India.

${ }^{\mathrm{f}}$ Cauvery River- Mysore, India. 
Table 5. Comparison of proposed method with reported methods

\begin{tabular}{|c|c|c|c|c|}
\hline Method & $\begin{array}{l}\text { Beer's Law range } \\
\quad(\mu \mathrm{g} / \mathrm{mL})\end{array}$ & $\begin{array}{l}\text { Molar absorptivity } \\
\quad\left(\mathrm{L} \mathrm{mol}^{-1} \mathrm{~cm}^{-1}\right)\end{array}$ & Remarks & References \\
\hline Phenosafranine & - & $6.65 \times 10^{4}$ & Several ions interfere & {$[9]$} \\
\hline N,N'-diphenylbenzamidne & $0.1-1.2$ & $1.8 \times 10^{5}$ & Based on the extraction & {$[15]$} \\
\hline $\begin{array}{l}\text { 4-(4'-N,N-Dimethylamino phenyl) } \\
\text { urazol }\end{array}$ & $0.016-6.13$ & - & $\begin{array}{l}\text { Need extraction, control of } \mathrm{pH}, 30^{\circ} \mathrm{C} \\
\text { and high interfere with } \mathrm{Fe}^{3+}\end{array}$ & {$[19]$} \\
\hline $\begin{array}{l}\text { 9,10-phenanthaquinone } \\
\text { monoethylthiosemicarb-azone }\end{array}$ & $0.2-10$ & $2.2 \times 10^{4}$ & $\begin{array}{l}\text { Separation by flotation and solid-phase } \\
\text { extraction, less sensitive }\end{array}$ & {$[21]$} \\
\hline Trifluperazine hydrochloride & $0.5-6.5$ & $2.14 \times 10^{4}$ & Less sensitive & {$[22]$} \\
\hline Bromopyrogallol red + CTAB & - & $3.5 \times 10^{4}$ & Several ions interfere, less sensitive & {$[46]$} \\
\hline $\mathrm{MBTH}+\mathrm{IDB}$ & $0.1-4$ & $4.5 \times 10^{4}$ & $\begin{array}{l}\text { Simple, rapid, sensitive, stablecolor, } \\
\text { less interference and no need } \\
\text { prior extraction, control of } \mathrm{pH} \text { or } \\
\text { temperature }\end{array}$ & $\begin{array}{l}\text { Proposed } \\
\text { method }\end{array}$ \\
\hline
\end{tabular}

amounts and those detected by proposed method and the reported methods, indicating that the proposed method is as accurate and precise as the reported methods. Comparative study between the proposed method and some reported methods has shown that, the proposed method is simple, rapid, and highly sensitive than these methods in literature as shown in Table 5.

\section{Precision and accuracy of the proposed method}

The precision and accuracy of the proposed method were studied by analyzing solutions containing of $0.5,1.5$, and $3 \mu \mathrm{g} / \mathrm{mL}$ of thallium(III) which gave RSD of $0.9,0.5$ and $0.3 \%$, respectively, when tested with ten replicate determinations of each concentration. These lower values of RSD obtained indicate the high precision and accuracy of the method.

\section{Application of the method in synthetic mixtures}

Certified samples of thallium were not available so the proposed method was applied to a variety of synthetic samples to evaluate its effectiveness. The composition of the synthetic mixtures was selected to contain the common metal ions that usually accompany thallium in natural samples [33]. The mixtures were analyzed by recommended procedure and the obtained results showed good recoveries for thallium(III) as shown in Table 6. Also the proposed method was applied for the determination of thallium(III) and thallium(I) as a mixture,
Table 6. Determination of Tl(III) in synthetic mixtures of common metal ions that usually accompany thallium in nature

\begin{tabular}{|c|c|c|c|}
\hline Mixture & $\begin{array}{c}\text { Thallium(III) } \\
\text { added }(\mu \mathrm{g} / \mathrm{mL})\end{array}$ & 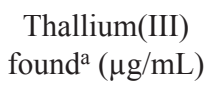 & $\begin{array}{c}\text { Mean } \\
\text { Recovery }(\%)\end{array}$ \\
\hline $\begin{array}{l}\mathrm{Zn}^{2+}, \mathrm{Fe}^{3+\mathrm{b}}, \\
\mathrm{Pb}^{2+}\end{array}$ & 1 & $0.98 \pm 1.61$ & 98.0 \\
\hline $\begin{array}{l}\mathrm{Zn}^{2+}, \mathrm{Fe}^{3+\mathrm{b}}, \\
\mathrm{Pb}^{2+}\end{array}$ & 3 & $2.94 \pm 0.867$ & 98.0 \\
\hline $\begin{array}{l}\mathrm{Zn}^{2+}, \mathrm{Cd}^{2+}, \\
\mathrm{Ni}^{2+}\end{array}$ & 1 & $0.97 \pm 1.98$ & 97.0 \\
\hline $\begin{array}{l}\mathrm{Zn}^{2+}, \mathrm{Cd}^{2+}, \\
\mathrm{Ni}^{2+}\end{array}$ & 3 & $2.92 \pm 0.71$ & 97.3 \\
\hline $\begin{array}{l}\mathrm{Cu}^{2+}, \mathrm{Zn}^{2+}, \\
\mathrm{Na}^{+}\end{array}$ & 1 & $1.01 \pm 0.83$ & 101.0 \\
\hline $\begin{array}{l}\mathrm{Cu}^{2+}, \mathrm{Zn}^{2+}, \\
\mathrm{Na}^{+}\end{array}$ & 3 & $3.02 \pm 0.64$ & 100.6 \\
\hline
\end{tabular}

${ }^{\text {a }}$ Mean \pm Relative Standard Deviation $(n=5)$.

${ }^{\mathrm{b}}$ Masking by the addition of $2 \mathrm{~mL}$ of $0.3 \mathrm{M}$ sodium fluoride.

since the oxidation of thallium(I) to thallium(III) was quantitative, and thallium(I) species did not interfere with the spectrophotometric determination of thallium(III). The positive outcomes of the results are as in Table 7. 
Table 7. Determination of Tl(I) and Tl(III) by proposed method of Tl(III) with and without oxidation with bromine water

\begin{tabular}{|c|c|c|c|c|c|c|}
\hline \multicolumn{2}{|c|}{ Thallium added $(\mu \mathrm{g} / \mathrm{mL})$} & \multicolumn{2}{|c|}{ Thallium found ${ }^{\mathrm{a}}(\mu \mathrm{g} / \mathrm{mL})$} & \multirow[t]{2}{*}{ Difference } & \multicolumn{2}{|c|}{ Mean Recovery (\%) } \\
\hline (I) & (III) & Without oxidation & With oxidation & & (I) & (III) \\
\hline 1 & 1 & $0.99 \pm 1.32$ & $1.98 \pm 1.31$ & 0.99 & 99.0 & 99.0 \\
\hline 1.5 & 1.5 & $1.51 \pm 0.55$ & $3.01 \pm 0.33$ & 1.50 & 100.0 & 100.6 \\
\hline
\end{tabular}

${ }^{\mathrm{a}}$ Mean \pm Relative Standard Deviation $(n=5)$.

\section{Conclusion}

The proposed method that involves coupling of MBTH with IDB as reagents in the determination of thallium(III) has advantages such as simplicity, selectivity, stability and sensitivity as compared to some reported spectrophotometric methods as shown in Table 4. The color development was maximum and involves less stringent control of experimental conditions including duration for time analysis and $\mathrm{pH}$ control, which make this method easy and more practical as far as the procedure is concerned. In addition, the proposed method neither involves solvent extraction nor employs sophisticated instruments. The method has high tolerance limit for interfering species that are commonly present with thallium which is another added advantage. Thus, it can be concluded that this proposed method can be applied for the determination of thallium in various analytical procedures.

\section{Experimental}

\section{Instruments}

A JASCO Model UVIDEC-610 UV/VIS spectrophotometer with $1 \mathrm{~cm}$-matched cells was used for all the spectral measurements. A pH-meter, EQUIP-TRONICS Model EQ-614 was employed for measuring $\mathrm{pH}$ values.

\section{Reagents and solutions}

All the chemicals used were of analytical reagent grade or the highest purity available. Doubly distilled water was used throughout the experiments for dilution of the reagents and samples. Glass vessels were cleaned by soaking in acidified solution of $\mathrm{K}_{2} \mathrm{Cr}_{2} \mathrm{O}_{7}$, followed by washing with concentrated $\mathrm{HNO}_{3}$ and rinsing several times with distilled water.

Standard thallium (III) solution $(1000 \mu \mathrm{g} / \mathrm{mL})$

A stock solution was prepared by dissolving $0.112 \mathrm{~g}$ of $\mathrm{Tl}_{2} \mathrm{O}_{3}$ (Fluka, Switzerland) in $50 \mathrm{~mL}$ of $2 \mathrm{~N}$ sulphuric acid and kept aside for over night, followed by diluting to $100 \mathrm{~mL}$ in a calibrated flask with distilled water. The stock solution was standardized titrimetrically [48], and solutions of lower concentrations were prepared by diluting the standard solution as and when required.

Standard thallium (I) solution $(1000 \mu \mathrm{g} / \mathrm{mL})$

This solution was prepared by dissolving $0.117 \mathrm{~g}$ of $\mathrm{TlCl}$ (99.99\%, Fluka, Switzerland) in $100 \mathrm{ml}$ of distilled water, and solutions of lower concentrations were prepared by diluting this solution as and whenever required.

\section{3-Methyl-2-benzothiazolinonehydrazone hydrochloride (MBTH)}

A $0.05 \%(\mathrm{w} / \mathrm{v})$ aqueous solution of MBTH was freshly prepared by dissolving the requisite amount of MBTH (Merck, Darmstadt, Germany) in distilled water and stored in dark colored bottle in a refrigerator maintaining temperature of $0-10$ ${ }^{\circ} \mathrm{C}$. This solution thus stored was stable for 10 days.

Iminodibenzyl (IDB)

A $0.1 \%(w / v)$ solution of IDB was prepared by dissolving a requisite amount of IDB (BDH, England) in alcohol and stored in dark colored bottle in refrigerator maintaining temperature of $0-10{ }^{\circ} \mathrm{C}$. The solution thus stored was stable for one month.

Orthophosphoric acid

A 3M orthophosphoric acid solution was prepared by suitable dilution of concentrated orthophosphoric acid (Ranbaxy Laboratories Ltd., Hariana, India) in distilled water.

Solutions of foreign ions

Solutions containing suitable concentrations of potentially interfering ions were prepared in distilled water or appropriate solvent, whenever required.

Other solutions

All the other solutions used throughout the experiments like sulphuric acid, bromine water, sulphamic acid and sodium 
fluoride were prepared by dissolving requisite amounts of the reagents in distilled water.

\section{Recommended procedure}

An aliquot of a sample solution containing 1-40 $\mathrm{gg}$ of thallium(III) was transferred into a series of $10 \mathrm{ml}$ calibrated flasks, to which $1 \mathrm{ml}$ of $0.05 \%$ of MBTH, $1 \mathrm{ml}$ of $0.1 \%$ IDB and $1 \mathrm{ml}$ of $3 \mathrm{M}$ orthophosphoric acid were added. Then the mixture was diluted up to the mark with alcohol and mixed thoroughly. The blue color which developed instantaneously was stable for 36 hours. The absorbance was measured at $660 \mathrm{~nm}$ against a reagent blank prepared in the same manner, but containing no thallium. The thallium(III) content was determined from the standard calibration graph constructed by this procedure.

\section{Determination of thallium in water samples}

Determination of thallium was carried out in environmental samples that tested negative for thallium. The spiked river, lake and tap water samples containing necessary quantity of thallium within the Beer's law limit were applied for the analysis. The spectrophotometric determination for the thallium analysis was carried out as per the procedure outlined above.

\section{Determination of thallium in urine samples}

Thallium may enter human body either deliberately as a component of drug or through contamination in water or food etc. Thus, its quantification in biological fluid is anticipated. A known amount of thallium(III) was added to $30 \mathrm{~mL}$ of healthy human urine that was previously tested negative for thallium, which was taken in a $100 \mathrm{~mL}$ micro-Kjeldahl flask, a glass bead and $5 \mathrm{~mL}$ of concentrated nitric acid were added and the flask was placed on the digester under gentle heating. When the initial brisk reaction was over, the solution was removed and cooled. Then $1 \mathrm{~mL}$ of concentrated sulphuric acid was added carefully followed by the addition of $1 \mathrm{~mL}$ of $70 \%$ perchloric acid and heating was continued to dense white fumes. Further, heating was carried out for at least $30 \mathrm{~min}$, followed by cooling. The contents of the flask were filtered and diluted up to the mark with distilled water in $100 \mathrm{~mL}$ calibrated flask. A suitable aliquot of urine sample was taken and analyzed by using the procedure outlined earlier.

\section{Determination of thallium (I) and thallium (III) in the mixture}

For the determination of thallium (I) in a composite mixture containing both oxidation states of thallium, samples containing equal quantity of spiked thallium (I) and thallium (III) was taken in two $10 \mathrm{~mL}$ standard flasks. Recommended procedure was carried out for one standard flask, and thallium (III) was determined from Beer's law graph. $0.1 \mathrm{~mL}(1 \%)$ bromine water was added to the second standard flask to oxidize thallium(I) to thallium(III) and heated to near dryness. Then
$0.2 \mathrm{~mL}$ phenol was added to remove any excess of bromine water and the recommended procedure was carried out. So thallium(I) was determined by the difference in obtained in the oxidized [representing both $\mathrm{Tl}(\mathrm{I})$ and $\mathrm{Tl}(\mathrm{III})$ ] and the unoxidised [representing Tl(III) samples].

\section{Determination of thallium in synthetic mixtures}

Certified samples of thallium were not available, therefore, composition of spiked synthetic mixtures of common metal ions that usually accompany thallium in natural samples were prepared in concentrations below the tolerance limit [33], and analyzed directly by proposed method without any prior separation of thallium.

\section{Acknowledgements}

One of the authors (Naef Ghllab. S. Al-Tayar) is grateful to the Yemen Gas Company (Ministry of Oil and Minerals) and Ministry of Higher Education (Republic of Yemen) for awarding a fellowship and financial assistance. Authors are grateful to the University of Mysore for providing the laboratory facilities and granting permission to carryout the research work.

\section{References}

1. Patty, F. A., Industrial hygiene and toxicology. Vol. II, Interscience Publishers, New York. 1962.

2. Younger, D. S., in Textbook of Neurology, P. Rowland (ed), p. 987, Williams \& Wilkins, Baltimore, 1995.

3. Hassanien, M. M.; Abou-El-Sherbini, K. H. S.; Mostafa, G. A. E. Talanta 2003, 59, 383-392.

4. Mamoru, H.; Kazushi, T.; Mariko, O. O.; Mitsutoshi, T.; Naomi, H. Industrial Health 1998, 36, 300-303.

5. Sitting, M., Handbook of toxic and hazardous chemicals and carcinogens. Noyes Publication, New Jersey, USA. 1985.

6. Townshend, A., (Ed-in-Chief) Encyclopedia of Analytical Science, vol. 9, Academic Press, London. 1995.

7. http:/www.epa.gov/OGWDW/contaminants/basicinformation/ thallium.html, updated June 30th, 2009.

8. Wei, M. T.; Jiang, S. J. J. Anal. At. Spectrom. 1999, 14, $1177-$ 1181.

9. Liu, C.; Zhou, H.; Quin, L. Fenxi Huaxue 1986, 14, 142-144.

10. Hafez, M. A. H.; Kenawy, I. I. M.; Emam, M. E. H. Indian J. Chem., 1996, 35 (A), 79-84.

11. Zheng, G.; Guo, Z.; Zhao, Y.; Zhan, S. Fenxi Shiyanshi 1997, 16, 21-25.

12. Hong, S.; Li, Q. Y.; Mingdong,. Нuaxue Xuebao 1988, 46, 500506.

13. Agarwal, N.; Patel, K. S. Analysis 1991, 19, 134-135.

14. Deb, M. K.; Agnihotri, P. K.; Thakur, M.; Mishra, R. K. Chem. Spec. Bioavailab. 1998, 10, 53-60.

15. Patel, K. S.; Agarwal, N. Intern. J. Environ. Anal. Chem. 1992, 46, 63-70.

16. Namboothri, K. K.; Balasubramanian, N.; Ramakrishna, T. V. Talanta 1991, 38, 945-949.

17. Gowda, H. S.; Rekha, G. K. Indian J. Chem. 1989, 28A, 179-180.

18. Zhang, R.; Wang, H.; Wen, J. Fenxi Huaxue, Anal. Abstr. 1988, $16,111-113$. 
19. Rezae, B.; Mallkpour, S.; Khalili, H. Can. J. Anal. Sci. Spect. 2005, 50, 227-234.

20. Revanasiddappa, H. D.; Kiran Kumar T. N. Turk. J. Chem. 2005, 29, 265-272.

21. Abou-El-Sherbini, K. S.; Mostafa, G. A. E.; Hassanien. M. M. Anal. Sci. 2003, 19, 1269-1275.

22. Revanasiddappa, H. D.; Kiran Kumar, T. N. Anal. Sci. 2002, 18, 1131-1135.

23. Hosseini, M. S.; Naseri, Y. Anal.. Sci. 2003, 19, 1505-1508.

24. Heumann, K. G.; Kastenmayer, P.; Zeininger, H. Fresen. J. Anal. Chem. 1981, 306, 173-177.

25. Cheam, V.; Lechner, J.; Desrosiers, R.; Sekerka, I. Intern. J. Environ. Anal. Chem. 1996, 63, 153-165.

26. Baiocchi, C.; Giacosa, D.; Saini, G.; Cavalli, P.; Omenetto, N.; Passarella, R.; Polettini, A.; Trincherini, P. R. Intern. J. Environ. Anal. Chem. 1994, 55, 211-218.

27. Lu, T. H.; Sun, I. W. Electroanal. 1998, 10, 1052-1056.

28. Medek, P.; Pavlikova, J.; Zbiral, J.; Cizmarova, E.; Kuban, V. Int. J. Environ. Anal. Chem. 2001, 81, 207-219.

29. Mestek, O.; koplik, R.; Fingerova, H.; Suchanek, M. J. Anal. Atom. Spectrom. 2000, 15, 403-407.

30. Calderoni, G.; Ferri, T. Talanta 1982, 29, 371-375.

31. Bondelli, J. E.; Taylor, H. E.; Skogerboe, R. K. Anal. Chim. Acta 1980, 118, 243-256.

32. Ciszewski, A.; Wasiak, W.; Ciszewska, W. Anal. Chim. Acta 1997, $343,225-229$.
33. Shams, E.; Yekehtaz, M. Anal. Sci. 2002, 18, 993-996.

34. Ivanova, E.; Yan, X. P.; Mol, W. V.; Adams, F. Analyst 1997, 122, 667-671.

35. Zendelovska, D.; Stafilov, T. Anal. Sci. 2001, 17, 425-428.

36. Lime, I.; Kaiser, G.; Sager, M.; Tolg, G. Anal. Chim. Acta, 1984, 158, 179-197.

37. Dadfarnia, S., Assadollahi,T., Haji Shabani A. M., J. Hazard. Mater. 2007, 148, 446-452.

38. Mohammed, A. T. Bull. Korean Chem. Soc. 2003, 24, 1177-1180.

39. Hubert, A. E.; Chao, T. T. Talanta 1985, 32, 568-570.

40. Carpenter, R. C. Anal. Chim. Acta., 1981, 125, 209-213.

41. Anastas P. T.; Kirchoff, M. ACC. Chem. Res. 2002, 35, 686-694

42. Eugene S.; Thomas W. S.; Thomas R. H.; Walter E.; James L. N.; Anal. Chem. 1961, 33, 722-725

43. Pays, M.; Bourdon, R. ; Beljean, M. Anal. Chim. Acta 1969, 47, 101-111.

44. Nagaraja, P.; Silwadi, M.F.; Syed, A. A. Chim. Acta Turcica 1999, 27, 21-26.

45. Ariel, M.; Bach, D. Analyst 1963, 88, 30-35

46. Ladzinsk-Kulinska, H. Chem. Anal. (Warsaw) 1986, 31, 843-849.

47. Nagaraja, P.; Al-Tayar, N. G. S.; Siva Kumar, A. Int. J. $A O A C$ 2008, 91, 1116-1123.

48. Gowda, H. S.; Shakunthala, R.; Subrahamanya, U. Indian J. Chem. 1981, 20A, 68-71. 